\title{
Assessment of the impact of cyclones on the annual sediment budget in a Pacific Island catchment using a hydro-sedimentological model
}

\author{
E. Jorquera $^{a}$, J. F. Rodríguez ${ }^{\mathrm{a}}$ (D) P. M. Saco ${ }^{\mathrm{a}}$ (i) and H. Timmermans ${ }^{\mathrm{b}}$ \\ ${ }^{a}$ School of Engineering and Centre for Water Security and Environmental Sustainability, The University of \\ Newcastle, Callaghan 2308, Australia; ${ }^{b}$ Secretariat of the Pacific Regional Environment Programme, Suva \\ Office, Fiji \\ Emails: Eliana.jorquera@uon.edu.au; Jose.rodriguez@newcastle.edu.au; Patricia.saco@newcastle.edu.au;
} hermant@sprep.org

\begin{abstract}
Pacific Islands are one of the world hotspots for climate change, with sea level rise (SLR) and increases in tropical cyclones (TC) activity posing a serious threat to coastal areas and ecosystems. Precipitation and extreme sea level events associated with TC generate floods that cause damage to agriculture, home and businesses and also produce considerable amounts of sediment that end up in the adjacent coastal areas. Our study focuses on coastal wetlands that receive sediments from the Dreketi River catchment on the northern coast of Vanua Levu, Fiji which are likely to be heavily affected by climate change. Recent studies have identified this area of the coast as a storm tide high-risk zone, and also that the Dreketi River catchment contributes most of the sediment to the adjacent Great Sea Reef (GSR) or Cakaulevu.
\end{abstract}

The purpose of this work is to identify the impact of TC on the annual sediment yield through a physicallybased hydro-sedimentological model. To address this, the period from 1970 to 2017 was simulated daily with SWAT, obtaining flow and sediment discharges at the outlet of Dreketi River catchment. For the same period, the cyclones within a radius of $600 \mathrm{Km}$ of the barycentre of the catchment were analysed using the Southwest Pacific Enhanced Archive of Tropical Cyclones (SPEArTC). Two types of analysis were performed. The first one focused on the meteorological data, and the aim was to relate the maximum rainfall in the catchment with TC. The second one was based on the results of the hydro-sedimentological model assessing two aspects; i) which percentage of the annual sediment budget can be explained by TC, and ii) in how many cases the maximum annual sediment yield is due to a TC.

Regarding the meteorological data, three meteorological stations were analysed with focus on the maximum daily rainfall. It was found that a TC caused the extreme values in each station in 10, 13 and 15 out of 45 years, respectively. However, the modelling results showed that on average $14 \%$ of the total annual sediment yield is related to TC and that TC caused the maximum annual sediment discharge in 19 out of 45 years (42\%). These results indicate that even though TCs could not always generate the highest daily value during a year, due to the duration of the event and its intensity they have a significant impact on the annual sediment budget.

Keywords: Hydro-sedimentological modelling, Pacific Island Nations, tropical cyclones, SWAT 
Jorquera et al. Assessment of the impact of cyclones on the annual sediment budget in a Pacific Island River catchment using a hydro-sedimentological model.

\section{INTRODUCTION}

Pacific Islands are among the most vulnerable areas to climate change in general and sea level rise (SLR) and tropical cyclones (TC) in particular (Magee et al., 2016b; Mimura, 1999; Nunn, 2012; Nunn \& Mimura, 1997). In Fiji, flood events in rivers are the most relevant processes affecting channel stability and environmental and socio-economic conditions on floodplains (Kostaschuk et al., 2001). Several works suggest that the intense precipitation and extreme sea level events associated with TC generate floods that cause damage to agriculture, home and businesses (Magee et al., 2016b; Terry et al., 2004). These extreme events also generate considerable amounts of sediment that end up on the coastal areas and the adjacent waters. Coastal wetlands are extremely important because they capture sediment and pollutants, and their capacity to survive SLR and TC is inextricably linked to the fate of the significant marine areas nearby. Previous work has shown that coastal wetlands can take advantage of increased sediment loads in order to build up elevation and keep up with SLR

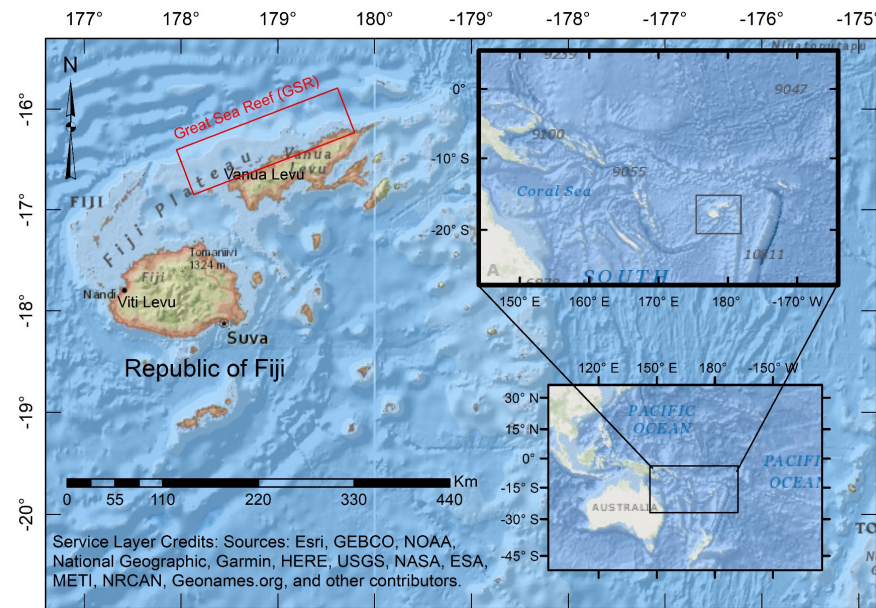

Figure 1. Geographic location of Republic of Fiji (Rodriguez et al., 2017; Sandi et al., 2018).

Recent studies have identified the southern northwest coast of Vanua Levu as a storm tide high-risk zone (McInnes et al., 2014). This area belongs to the Great Sea Reef or Cakaulevu, the third most extended continuous barrier reef system in the world (Figure 1). It has an extension of $260 \mathrm{~km}$ from the northern coast of Vanua Levu to the westward side of the Yasawa Island chain (SPREP, 2017). The area adjacent to the central part of Vanua Levu is known as Qoliqoli Cokovata. Qoliqoli is a Fijian term referring to the region from the foreshore to the fringing reefs (Sloan \& Chand, 2016). In 2003, Qoliqoli Cokovata was recognised as one of five marine priority conservation areas in Fiji, due to its riches of marine biodiversity and endemic species. In 2018 it was designated as Ramsar Site (No. 2331), covering an area of 134000 ha (Ramsar Convention Secretariat, 2019). The major threats to the site include chemical and wastewater run-off from neighbouring settlements, sugarcane farms and a mill, as well as increased sediment loading from forestry and gravel mining operations. It has been acknowledged for this area that terrestrially-based runoff has a negative impact on coral reef health (SPREP, 2017). We have selected for this study the Dreketi River catchment due to its significant contribution of sediments to the qoliqoli (Brown et al., 2017), and also because of the presence of a large mangrove wetland at the mouth of the river.

The purpose of this work is to identify the impact of TC on the annual sediment yield through a physicallybased hydro-sedimentological model. To address this, the period from 1970 to 2017 was simulated daily with SWAT, obtaining flow and sediment discharges at the outlet of Dreketi River catchment. For the same period, the cyclones within a radius of $600 \mathrm{Km}$ of the barycentre of the catchment were analysed using the Southwest Pacific Enhanced Archive of Tropical Cyclones (SPEArTC). Two types of analysis were performed. The first one focused on the meteorological data, and the aim was to relate the maximum rainfall in the catchment with TC. The second one was based on the results of the hydro-sedimentological model assessing two aspects; i) which percentage of the annual sediment budget can be explained by $\mathrm{TC}$, and ii) in how many cases the maximum annual sediment yield is due to a TC.

\section{MATERIALS AND METHODS}

\subsection{Description of the study site}

The Dreketi River catchment is located in the province of Macuata, in the Northern Division of Vanua Levu between $16^{\circ} 37^{\prime}$ and $16^{\circ} 32^{\prime}$ south latitude and $178^{\circ} 49^{\prime}$ and $179^{\circ} 19^{\prime}$ east longitude (Figure 2 ). It has an area of $825 \mathrm{~km}^{2}$ with altitude varying from $3 \mathrm{~m}$ to $919 \mathrm{~m}$ above sea level (masl). The main river (Dreketi) has a total length of $73 \mathrm{~km}$. The confluence of Nanenivuda and Korovuli rivers give origin to the Dreketi River, and downstream its major tributaries are Nasuva, Seaqaqa, Vumbelebele and Naua rivers.

The study area has a tropical marine climate, with fairly small variations in temperature during the year. During the coldest months, Jun, July and August, the average maximum temperature is only one degree lower, and the 
Jorquera et al. Assessment of the impact of cyclones on the annual sediment budget in a Pacific Island River catchment using a hydro-sedimentological model.

average minimum is less than four degrees lower than the hottest month. Rainfall is highly variable during the year with two distinct seasons, the wet season from November to April and the dry season from May to October. During the wet season, the average rainfall reaches $300 \mathrm{~mm}$ per month, while in the dry season, the average monthly rainfall is $80 \mathrm{~mm}$ (FMS, 2006).

Forest and grassland are the dominant land use within the area of study, occupying nearly $80 \%$. Approximately

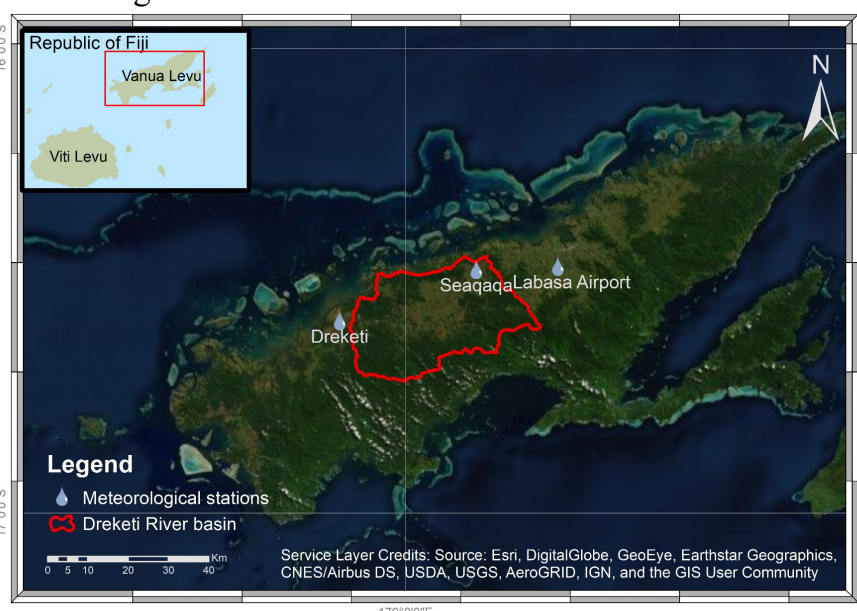

Figure 2. Geographic location of Dreketi river catchment and its meteorological stations. $20 \%$ of the land within the catchment is used for agricultural activities; these are mostly sugarcane crops and a small percentage of coconut plantations. Other minor land uses are rice near the mouth of the Dreketi River and taro, cassava and kava in the villages, forestry and gravel extraction. Surface waters and low-density urban settlements occupy the rest of the area. (PCRAFI, 2010).

\subsection{Catchment modelling}

SWAT can be described as a physicallybased hydro-sedimentological balance model. It requires climatic inputs because the moisture and energy drive all other processes simulated in the catchment. First, the catchment is divided into subcatchments using hydrological and topographic criteria. Later, according to land use, soil type and slope; each sub-catchment is divided again into hydrologic response units (HRUs) where those properties are homogeneous (Neitsch et al., 2011). The processes simulated by SWAT may be classified as climatic and hydrological. The hydrological processes are separated into two components: land phase and routing phase. In the former, the balance equation is solved in each HRU, estimating the amount of water that will reach the channel network. The balance equation expressed in $\mathrm{mm}$ is (Arnold et al., 1998):

$$
S W_{t}=S W_{0}+\sum_{i=1}^{t}\left(R_{i}-Q_{\text {surf }_{i}}-E T_{i}-Q_{l}-w_{\text {seep }_{i}}-Q_{g w_{i}}\right)
$$

where $\mathrm{SW}_{\mathrm{t}}$ is the soil water content at day $\mathrm{t}, \mathrm{SW}_{0}$ is the initial soil water content. All the variables with the subscript $\mathrm{i}$ referred to the day $\mathrm{i}$, being $\mathrm{R}$ the precipitation, $\mathrm{Q}_{\text {surf }}$ surface runoff, ET actual evapotranspiration, $\mathrm{W}_{\text {seep }}$ : flow entering the vadose zone and $\mathrm{Q}_{\mathrm{gw}}$ the return flow or groundwater flow. In the latter, the amount of surface runoff is routed through the channel network, and the sediments, nutrients and pollutants yielded will be transported as a function of that runoff. The sediment yield is obtained from the MUSLE equation applied to each HRU.

$$
y=11.8\left(Q q_{p}\right)^{0.56} K C S L P
$$

where: $y$ is the sediment yield (tonnes), Q runoff volume $\left(\mathrm{m}^{3}\right)$ and $\mathrm{q}_{\mathrm{p}}$ the peak runoff rate $\left(\mathrm{m}^{3} / \mathrm{s}\right) . \mathrm{K}, \mathrm{C}$, SL and $\mathrm{P}$ are the standard USLE factors for soil erodibility, crop management, slope length-gradient and erosion control practice, respectively (Williams \& Berndt, 1977). The model also simulates nitrogen and phosphorus.

The model first reads or generates all the climate-related variables, and then separates runoff and infiltration using the NRCS-CN method (Natural Resources Conservation Service \& United States Department of Agriculture, 1986). SWAT requires three maps: elevation grid (raster), land use and soil types. SWAT has onboard pre-defined databases that relate land use, and soil types with hydrological, erosion and plant growth parameters, among others. The user can match those with local data, or can add parameters known beforehand.

For the Dreketi river catchment, a Digital Elevation Model (DEM) with a spatial resolution of one arc-second $(30 \mathrm{x}$ 30m) was obtained from the Shuttle Radar Topography Mission (SRTM DEM) (https://www2.jpl.nasa.gov/srtm/dataprod.htm), retrieved from https://earthexplorer.usgs.gov/. The information was processed using the free and open source Geographic Information System (GIS) software GRASS (Geographic Resources Analysis Support System) (http://grass.osgeo.org), generating a depressionless elevation map and a flow direction map using the tool provided based on the work of (Jenson \& Domingue, 1988). The soil map was retrieved from the Food and Agriculture Organization (FAO) of the United Nations (UN) and the UN Educational, Scientific and Cultural Organization (UNESCO) published and updated since 1981 (Sanchez et al., 2009). A vectorial land use map was obtained from the Pacific Catastrophe Risk 
Jorquera et al. Assessment of the impact of cyclones on the annual sediment budget in a Pacific Island River catchment using a hydro-sedimentological model.

Assessment and Financing Initiative (PCRAFI) - Pacific Risk Information System - OpenDRI repository for the Pacific Region (http://pcrafi.spc.int/) (PCRAFI, 2010).

The meteorological data for the catchment consisted of daily precipitation, maximum and minimum air temperature, wind speed and relative humidity for three stations: Dreketi, Labasa Airport and Seaqaqa, obtained from the Fiji Meteorological Service.

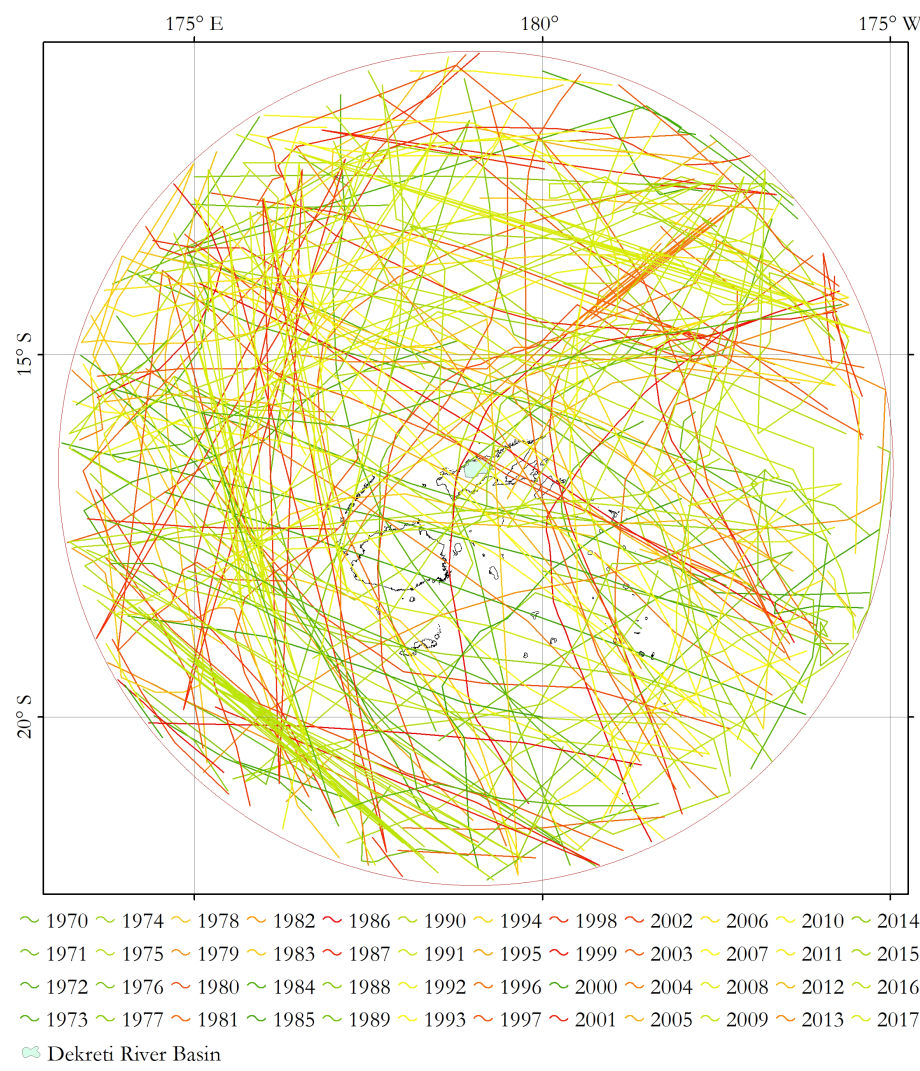

Figure 3. Cyclones from the SPEArTC from 1970 to 2017

\subsection{Tropical cyclones analysis}

One of the most destructive natural hazard in the tropical South Pacific Area is the impact of tropical cyclones (TCs) (Lafale et al., 2018; Magee et al., 2016b; McInnes et al., 2014; Terry \& Gienko, 2010) in terms of both number the people affected and also on the monetary losses due to the damages. This is due to a combination of two factors: the high vulnerability of the Pacific Islands and the severity of the events.

There are several databases of the regional tropical cyclone information for the Southern Hemisphere, one of them is Southwest Pacific Enhanced Archive of Tropical Cyclones (SPEArTC), which has been acknowledged as the most complete repository for this area (Magee et al., 2016a). These data contain the coordinates and central pressures of each cyclone throughout its life at mostly 6-hourly intervals for the Cyclones since 1840. The approach of McInnes et al. (2014) was followed to assess the impact of TC on the Dreketi river catchment. It considers that cyclones will affect if their tracks are located within $600 \mathrm{~km}$ of the barycentre of the catchment $\left(17^{\circ} \mathrm{S} 178.5^{\circ} \mathrm{E}\right.$, Figure 3$)$.

Table 1. Cyclone associated with the maximum daily precipitation.

\begin{tabular}{|c|c|c|c|c|}
\hline Season & Seaqaqa & Dreketi & Labasa & $\begin{array}{c}\text { Duration } \\
\text { [days] }\end{array}$ \\
\hline $1972-1973$ & HENRIETTA & HENRIETTA & - & 2 \\
\hline $1977-1978$ & ERNIE & - & ERNIE & 4 \\
\hline $1978-1979$ & HD-1979-20 & HD-1979-20 & HD-1979-20 & 7 \\
\hline $1981-1982$ & HETTIE & HETTIE & HETTIE & 6 \\
\hline $1982-1983$ & OSCAR & - & - & 8 \\
\hline $1983-1984$ & CYRIL & CYRIL & CYRIL & 3 \\
\hline $1989-1990$ & RAE & RAE & RAE & 5 \\
\hline $1991-1992$ & - & INNIS & - & 2 \\
\hline $1992-1993$ & OLI & - & OLI & 3 \\
\hline $1996-1997$ & JUNE & JUNE & - & 5 \\
\hline $1997-1998$ & HSK0398 & - & SUSAN & 2 \\
\hline $1999-2000$ & NEIL & - & NEIL & 4 \\
\hline $2006-2007$ & NOT NAMED & - & NOT NAMED & 2 \\
\hline $2009-2010$ & - & - & TOMAS & 5 \\
\hline $2012-2013$ & EVAN & EVAN & EVAN & 6 \\
\hline $2015-2016$ & AMOS & - & - & 8 \\
\hline
\end{tabular}

\section{RESULTS}

\subsection{Maximum rainfall data and cyclones}

The maximum daily rainfall was determined in Labasa Airport, Seaqaqa and Dreketi stations, to establish the contribution of TC on those extreme values. The hydrological year was defined from July to June, to include the complete cyclone season (November to April). The maximum daily precipitation was TC-related in 13, 15 and 10 years, out of 45 years of analysis on Labasa Airport, Dreketi and Seaqaqa stations, respectively. Therefore, the

contribution of TC to extreme rainfall is once every $3,4.5$ and 3.5 years, respectively. 
Jorquera et al. Assessment of the impact of cyclones on the annual sediment budget in a Pacific Island River catchment using a hydro-sedimentological model.

Table 1 shows the cyclone and its duration associated with the maximum daily precipitation in the area. The cyclone duration was always longer than two days, so the maximum rainfall accumulated in two days to a week was analysed. Table 2 shows the cyclones related with the utmost precipitation for different durations in Labasa Airport station. It can be seen that the number of TC-related with the maximum annual precipitation increase with the duration considered. The other two stations showed similar patterns. The number of cyclones that generate the maximum weekly rainfall was 23 for Dreketi, 24 for Labasa and 26 for Seaqaqa.

Table 2. Cyclone associated with the maximum precipitation.

\begin{tabular}{|c|c|c|c|c|c|c|}
\hline Season & 2 days & 3 days & 4 days & 5 days & 6 days & 7 days \\
\hline $1972-1973$ & HENRIETTA & HENRIETTA & HENRIETTA & HENRIETTA & HENRIETTA & HENRIETTA \\
\hline $1973-1974$ & - & HD-1974-01 & HD-1974-01 & HD-1974-01 & HD-1974-01 & HD-1974-01 \\
\hline $1974-1975$ & - & - & - & HD-1975-17 & HD-1975-17 & HD-1975-17 \\
\hline 1977 - 1978 & ERNIE & CHARLES & CHARLES & CHARLES & CHARLES & CHARLES \\
\hline 1978 - 1979 & HD-1979-20 & HD-1979-20 & HD-1979-20 & HD-1979-20 & HD-1979-20 & HD-1979-20 \\
\hline 1979 - 1980 & TIA & TIA & TIA & TIA & PENI & PENI \\
\hline 1981 - 1982 & HETTIE & HETTIE & HETTIE & HETTIE & HETTIE & HETTIE \\
\hline $1982-1983$ & OSCAR & OSCAR & OSCAR & OSCAR & OSCAR & OSCAR \\
\hline $1983-1984$ & - & CYRIL & - & CYRIL & - & - \\
\hline 1985 - 1986 & KELI & - & MARTIN & - & MARTIN & MARTIN \\
\hline $1986-1987$ & RAJA & RAJA & RAJA & RAJA & RAJA & RAJA \\
\hline 1988 - 1989 & - & UNNAMED & UNNAMED & UNNAMED & UNNAMED & UNNAMED \\
\hline $1989-1990$ & RAE & RAE & RAE & RAE & RAE & RAE \\
\hline $1992-1993$ & OLI & OLI & OLI & OLI & OLI & OLI \\
\hline 1994 - 1995 & - & HSK1995 & HSK1995 & HSK1995 & HSK1995 & HSK1995 \\
\hline 1997 - 1998 & SUSAN & RON & RON & RON & RON & RON \\
\hline $1999-2000$ & NEIL & NEIL & NEIL & NEIL & NEIL & NEIL \\
\hline $2001-2002$ & - & - & - & - & TC 16P & TC 16P \\
\hline $2002-2003$ & AMI & AMI & AMI & AMI & AMI & AMI \\
\hline $2004-2005$ & - & SHEILA & SHEILA & SHEILA & SHEILA & SHEILA \\
\hline $2006-2007$ & NOT NAMED & NOT NAMED & NOT NAMED & NOT NAMED & NOT NAMED & NOT NAMED \\
\hline $2007-2008$ & - & - & - & - & ELISA & ELISA \\
\hline $2009-2010$ & - & TOMAS & TOMAS & TOMAS & TOMAS & TOMAS \\
\hline $2012-2013$ & EVAN & EVAN & EVAN & - & - & EVAN \\
\hline 2015 - 2016 & - & - & - & ZENA & ZENA & ZENA \\
\hline No. Cyclones & 15 & 20 & 20 & 21 & 23 & 24 \\
\hline
\end{tabular}

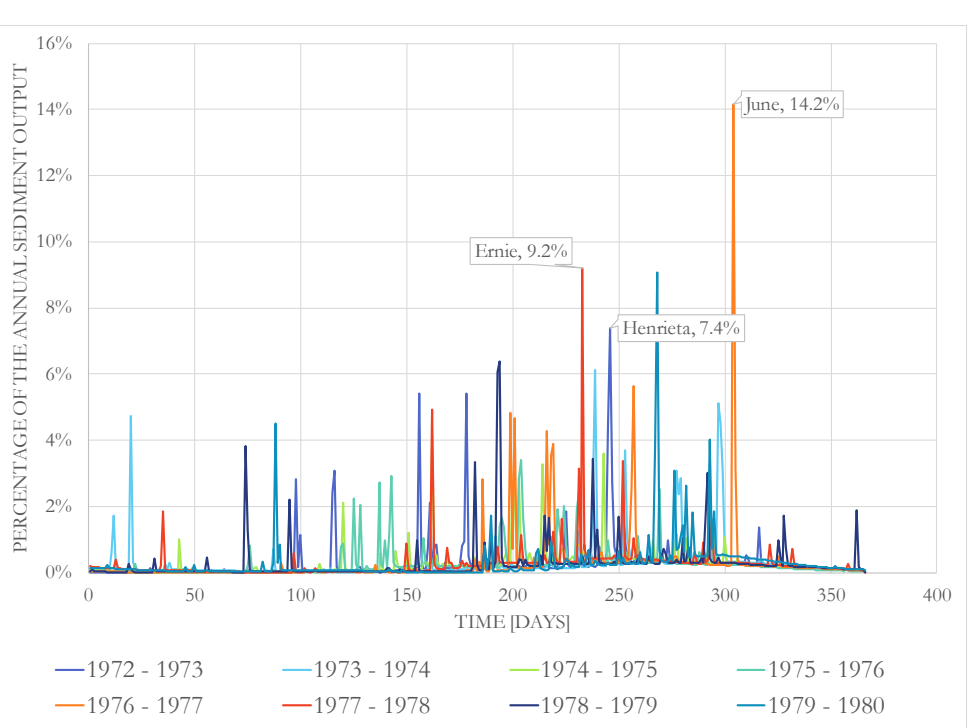

Figure 4. Sediment output of the catchment per hydrologic year as a percentage of the annual output

\subsection{Hydro- sedimentological modelling}

The results of the SWAT simulations were used to explore the effect of the cyclones on the sediment yield. The daily sediment output was calculated as a percentage of the total annual sediment yield. Figure 4 presents the results only for eight years. Similar results were found for the other years. The results show that most of the annual sediment budget is concentrated in less than 15 few episodes. On average, for the whole period, $78 \%$ of the sediment budget occur during the wet season, 
Jorquera et al. Assessment of the impact of cyclones on the annual sediment budget in a Pacific Island River catchment using a hydro-sedimentological model.

and the sediment yield due to cyclones accounts for $14 \%$ of the annual budget. In 19 out of 45 years, the maximum sediment discharge is related to a TC. The average sediment yield of those maximum values represents $9.4 \%$ of the annual sediment yield, with extreme cases as the cyclone RAJA in the season 19861987 that produced $34 \%$.

\section{DISCUSSION AND CONCLUSION}

This work assessed the influence of TC in a Pacific Island River catchment. Two main behaviours were analysed, the relationship between cyclones and maximum rainfall, and the impact of TC in the annual sediment budget.

In the first case, the maximum daily rainfall is TC-related in $27.7 \%$ of the cases. This frequency coincided with the rate of cyclone occurrence found by McInnes et al. (2014) for the Fiji region. Similar studies relating to maximum precipitation and cyclones were conducted in regional and global scales (Khouakhi et al., 2017; Knight \& Davis, 2009; Zhang et al., 2018). They all agree that one of the issues inherent to working with daily precipitation is that a single event with high intensities could be split and measured over two days. In our study, it was found that in some cases the maximum daily value was not related to a TC; however, the second or third highest value was related to a TC and produced the maximum sediment yield for a year. This explained why the frequency of maximum TC-related daily rainfall (1/3.67 years) is smaller than the maximum TC-related daily sediment yield (1/2.37 years). Other constraints highlighted by Knight and Davis (2009) is the windy conditions typical of TC that can influence the accuracy of the precipitation measurement. They suggested increasing the measured value based on wind speed. In this work, this correction factor was not applied due to the lack of wind speed data for some of the years.

The results from the hydro-sedimentological model indicate the important influence of TC in the catchment response. There is a strong relationship between sediment yield and TC, producing the maximum sediment yield in $42 \%$ of the cases and representing a $14 \%$ of annual sediment budget. Expected increases in TC activity due to climate change will certainly increase the relative contribution of TC-related events in the catchment sediment budget.

\section{ACKNOWLEDGMENTS}

This work has been possible due to funding from the University of Newcastle through a PhD scholarship. We are grateful to the Fiji Meteorological Service for providing the meteorological data and to Make Movono for help with the soil-use maps and meteorological information.

\section{REFERENCES}

Arnold, J. G., R. Srinivasan, R. S. Muttiah and J. R. Williams. (1998). Large area hydrologic modeling and assessment part I: Model Development. JAWRA Journal of the American Water Resources Association, 34(1), 73-89. doi:10.1111/j.1752-1688.1998.tb05961.x

Brown, C. J., S. D. Jupiter, S. Albert, C. J. Klein, S. Mangubhai, J. M. Maina, P. Mumby, J. Olley, B. StewartKoster, V. Tulloch and A. Wenger. (2017). Tracing the influence of land-use change on water quality and coral reefs using a Bayesian model. Sci Rep, 7(1), 4740. doi:10.1038/s41598-017-05031-7

Fiji Meteorological Service. (2006). The Climate of Fiji. Retrieved from http://www.met.gov.fj/index.php?page=fijiclimate

Jenson, S. K. and J. O. Domingue. (1988). Extracting topographic structure from digital elevation data for geographic information-system analysis. Photogrammetric Engineering and Remote Sensing, 54(11), 1593-1600.

Khouakhi, A., G. Villarini and G. A. Vecchi. (2017). Contribution of Tropical Cyclones to Rainfall at the Global Scale. Journal of Climate, 30(1), 359-372. doi:10.1175/jcli-d-16-0298.1

Knight, D. B. and R. E. Davis. (2009). Contribution of tropical cyclones to extreme rainfall events in the southeastern United States. Journal of Geophysical Research: Atmospheres, 114(D23). doi:10.1029/2009jd012511

Kostaschuk, R. A. Y., J. Terry and R. Raj. (2001). Tropical cyclones and floods in Fiji. Hydrological Sciences Journal, 46(3), 435-450. doi:10.1080/02626660109492837

Lafale, P. F., H. J. Diamond and C. L. Anderson. (2018). Effects of Climate Change on Extreme Events Relevant to the Pacific Islands. Retrieved https://assets.publishing.service.gov.uk/government/uploads/system/uploads/attachment_data/file/71 4530/5_Extreme_Events.pdf 
Jorquera et al. Assessment of the impact of cyclones on the annual sediment budget in a Pacific Island River catchment using a hydro-sedimentological model.

Magee, A. D., D. C. Verdon-Kidd and A. S. Kiem. (2016a). An intercomparison of tropical cyclone best-track products for the southwest Pacific. Natural Hazards and Earth System Sciences, 16(6), 1431-1447. doi:10.5194/nhess-16-1431-2016

Magee, A. D., D. C. Verdon-Kidd, A. S. Kiem and S. A. Royle. (2016b). Tropical cyclone perceptions, impacts and adaptation in the Southwest Pacific: an urban perspective from Fiji, Vanuatu and Tonga. Natural Hazards and Earth System Sciences, 16(5), 1091-1105. doi:10.5194/nhess-16-1091-2016

McInnes, K. L., K. J. E. Walsh, R. K. Hoeke, J. G. O’Grady, F. Colberg and G. D. Hubbert. (2014). Quantifying storm tide risk in Fiji due to climate variability and change. Global and Planetary Change, 116, 115129. doi:10.1016/j.gloplacha.2014.02.004

Mimura, N. (1999). Vulnerability of island countries in the South Pacific to sea level rise and climate change. Climate Research, 12(2-3), 137-143.

Natural Resources Conservation Service and United States Department of Agriculture. (1986). Urban Hydrology for Small Watersheds. from https://www.wcc.nrcs.usda.gov/ftpref/wntsc/H\&H/other/TR55documentation.pdf

Neitsch, S. L., J. G. Arnold, J. R. Kiniry and J. R. Williams. (2011). Soil and Water Assessment Tool Theoretical Documentation Version 2009. Retrieved from College Station, Texas.:

Nunn, P. D. (2012). Climate change and Pacific Island countries. Asia-Pacific Human Development Report Background Papers Series 2012/07, 1-89.

Nunn, P. D. and N. Mimura. (1997). VULNERABILITY OF SOUTH PACIFIC ISLAND NATIONS TO SEALEVEL RISE. Journal of Coastal Research, 133-151.

Pacific Catastrophe Risk Assessment and Financing Initiative (Cartographer). (2010). Republic of Fiji Landuse Landcover Map. Retrieved from http://pcrafi.spc.int/layers/geonode:fiji vector

Rodriguez, J. F., P. M. Saco, S. Sandi, N. Saintilan and G. Riccardi. (2017). Potential increase in coastal wetland vulnerability to sea-level rise suggested by considering hydrodynamic attenuation effects. Nat Commun, 8, 16094. doi:10.1038/ncomms16094

Sanchez, P. A., S. Ahamed, F. Carré, A. E. Hartemink, J. Hempel, J. Huising, P. Lagacherie, A. B. McBratney, N. J. McKenzie, M. d. L. Mendonça-Santos, B. Minasny, L. Montanarella, P. Okoth, C. A. Palm, J. D. Sachs, K. D. Shepherd, T.-G. Vågen, B. Vanlauwe, M. G. Walsh, L. A. Winowiecki and G.-L. Zhang. (2009). Digital Soil Map of the World. Science, 325(5941), 680-681. doi:10.1126/science. 1175084

Sandi, S. G., J. F. Rodríguez, N. Saintilan, G. Riccardi and P. M. Saco. (2018). Rising tides, rising gates: The complex ecogeomorphic response of coastal wetlands to sea-level rise and human interventions. Advances in Water Resources, 114, 135-148. doi:10.1016/j.advwatres.2018.02.006

Secretariat of the Pacific Regional Environment Programme. (2017). Ecosystem \& Socio-economic Resilience Analysis \& Mapping (ESRAM) for Macuata Province, Fiji. Retrieved from www.sprep.org/pebacc

Sloan, J. and K. Chand. (2016). An analysis of property rights in the Fijian qoliqoli. Marine Policy, 72, 76-81. doi:https://doi.org/10.1016/j.marpol.2016.06.019

Terry, J. P. and G. Gienko. (2010). Climatological aspects of South Pacific tropical cyclones, based on analysis of the RSMC-Nadi (Fiji) regional archive. Climate Research, 42(3), 223-233. doi:10.3354/cr00912

Terry, J. P., S. McGree and R. Raj. (2004). The Exceptional Flooding on Vanua Levu Island, Fiji, during Tropical Cyclone Ami in January 2003. Journal of Natural Disaster Science, 26(1), 27-36. doi:10.2328/jnds. 26.27

Williams, J. R. and H. D. Berndt. (1977). Sediment Yield Prediction Based on Watershed Hydrology. Transactions of the ASAE, 20(6), 1100-1104. doi:https://doi.org/10.13031/2013.35710

Zhang, Q., X. Gu, J. Li, P. Shi and V. P. Singh. (2018). The Impact of Tropical Cyclones on Extreme Precipitation over Coastal and Inland Areas of China and Its Association to ENSO. Journal of Climate, 31(5), 1865-1880. doi:10.1175/jcli-d-17-0474.1 